\title{
HUBUNGAN PERSEPSI PENGUNJUNG TERHADAP KUALITAS TRANSPORTASI UMUM DENGAN PEMILIHAN MODA TRANSPORTASI UMUM DI KAWASAN WISATA BUDAYA SURAKARTA
}

\author{
Agus Zulianto' ${ }^{1}$ Kuswanto Nurhadi2, Erma Fitria Rini ${ }^{3}$ \\ 1Program Studi Perencanaan Wilayah dan Kota Fakultas Teknik Universitas Sebelas Maret Surakarta \\ 2Program Studi Teknik Sipil Fakultas Teknik Universitas Sebelas Maret Surakarta
}

\begin{abstract}
Abstrak
Penelitian ini bertujuan untuk (1) mengidentifikasi kualitas transportasi umum menurut persepsi pengunjung; (2) mengetahui pilihan moda transportasi pengunjung di Kawasan Wisata Budaya Surakarta; (3) mengetahui hubungan persepsi pengunjung terhadap kualitas transportasi umum dengan pemilihan moda tansportasi umum di Kawasan Wisata Budaya Surakarta. Penelitian ini merupakan penelitian deskriptif kuantitatif. Teknik analisis data yang digunakan yaitu metode analisis crosstab. Hasil penelitian ini menunjukkan bahwa pengunjung di objek wisata budaya Kota Surakarta memberikan penilaian "cukup baik" (sebesar 4101). Penilaian koresponden terhadap kualitas transportasi umum Kota Surakarta memang cenderung cukup baik, tetapi penggunaan moda transportasi bukan umum lebih mendominasi dibandingkan penggunaan moda transportasi umum. Hasil penelitian ini menunjukkan nilai $p=0,000$ dan nilai $r=0,392$. Maka dapat disimpulkan persepsi kualitas transportasi umum dengan pemilihan moda transportasi umum memiliki hubungan yang bermakna dengan korelasi yang cukup kuat, makin tinggi persepsi kualitas transportasi umum maka makin bertambah pemilih moda transportasi umum.
\end{abstract}

Kata kunci: kualitas; pemilihan moda; persepsi; tranportasi umum; wisata budaya

\begin{abstract}
This research is aimed to 1) indentifying the quality of public transport by visitors perception; 2) knowing the choice of transport modes by visitor in Cultural Tourism of Surakarta; 3) knowing the relation of visitors perception to the quality of public transportwith the choice of public transport mode in Cultural Tourism of Surakarta. This research is a descriptive quantitative research. Data analysis technique used is crosstab analysis method. The results of research show that the visitors in Culturual Tourism of Surakarta gived "quite good" score (4101). Assessmentof correspondent on the quality of public transport in Surakarta is tends to quite good, but the use of non-public transportion is more dominating than the use of public transportation. The results of this study show the value $p=0,000$ and the value of $r=0.392$. it can be concluded that the perception of the quality of public transport with the selection of public transportation modes have a significant relationship with a fairly strong correlation, the higher the perception of the quality of public transport increase the votersof public transport mode.
\end{abstract}

Keywords: cultural tourism; moda choices; public transport; perception; quality

\section{PENDAHULUAN}

Transportasi merupakan salah satu sektor yang vital untuk mendukung kegiatan baik politik, ekonomi, sosial budaya/pariwisata dan pertahanan yang tidak dapat dipisah-pisahkan satu dengan yang lain. Salim (2004:6-7) mengungkapkan bahwa transportasi merupakan kegiatan pemindahan barang (muatan) dan penumpang dari suatu tempat ke tempat lain. Dalam transportasi terlihat ada dua unsur yang terpenting yaitu: 1) pemindahan/pergerakan (movement); 2) secara fisik mengubah tempat dari barang (komoditi) dan penumpang ke tempat lain. Transportasi memang dapat dibahas tanpa mengambil pariwisata sebagai pertimbangan, tetapi pariwisata tidak dapat berkembang tanpa adanya transportasi. Transportasi merupakan bagian integral dari industri pariwisata. Hal ini terutama disebabkan oleh perbaikan transportasi pariwisata (Tambunan, 2009:39). 
Keraton Surakarta, Mangkunegaran, Benteng Vastenburg, Museum Radya Pustaka, dan Taman Sriwedari merupakan salah satu tujuan wisata budaya di Kota Surakarta. Letaknya yang berada di pusat kota menjadikan kawasan wisata budaya ini mudah diakses. Selain letaknya yang strategis, objek wisata ini dilewati kendaraan umum yang memudahkan pengunjung untuk berkunjung ke objek wisata di kawasan wisata budaya. Sayangnya, keuntungan tersebut tidak diimbangi dengan kunjungan wisatawan menggunakan angkutan umum yang melewati kawasan wisata budaya tersebut. Penggunaan moda transportasi umum yang beroperasi di Kota Surakarta tampaknya belum mampu menjadi transportasi andalan bagi wisatawan yang berkunjung. Permasalahan inilah yang menjadikan peneliti merasa perlu untuk meneliti hubungan persepsi pengunjung terhadap kualitas transportasi umum dengan pemilihan moda transportasi umum di Kawasan Wisata Budaya Surakarta. Berdasarkan rumusan masalah tersebut, penelitian ini memiliki beberapa tujuan sebagai berikut: 1) mengidentifikasi kualitas transportasi umum menurut persepsi pengunjung; 2) mengetahui pilihan moda transportasi pengunjung di Kawasan Wisata Budaya Surakarta; 3) mengetahui hubungan persepsi pengunjung terhadap kualitas transportasi umum dan pemilihan moda tansportasi di Kawasan Wisata Budaya Surakarta.

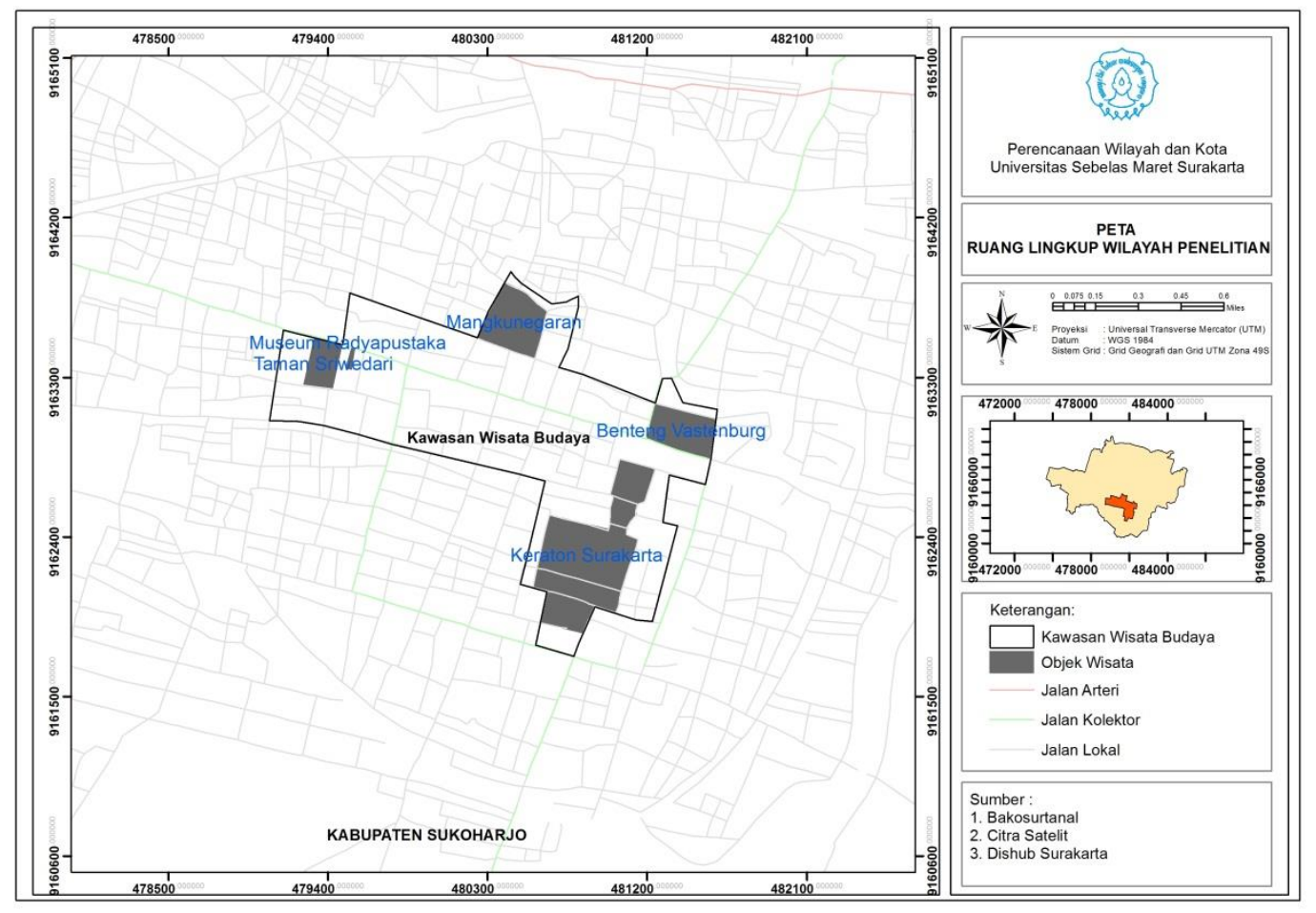

Gambar 1. Peta Objek Wisata Budaya di Kawasan Wisata Budaya Kota Surakarta

\section{TINJAUAN PUSTAKA}

Pariwisata budaya merupakan jenis wisata minat khusus dimana wisatawan yang termotivasi untuk mengunjungi tempat dengan keunikan budaya. Keunikan budaya tersebut dapat berwujud tata cara dan kebudayaan suatu bangsa, kehidupan sehari-hari, adat istiadat, upacara tradisional, bangunan/ arsitektur, musik dan tarian, seni pertunjukkan, maupun seni kerajinan dan sebagainya (Yudana dan Istijabatul, 2010). Sebagai sektor kompleks, pariwisata juga merealisasi industri kerajinan tangan, cinderamata, penginapan, dan transportasi (Salah Wahab dalam Nyoman, 2003:33). Hal ini menunjukkan bahwa transportasi memiliki keterkaitan dan peran yang penting terhadap pariwisata. Transportasi memang dapat dibahas tanpa mengambil pariwisata sebagai pertimbangan, tetapi pariwisata tidak dapat berkembang tanpa adanya transportasi. Berkembangnya pariwisata sejalan dengan perbaikan transportasi pariwisata (Tambunan, 2009:39). Bisa dikatakan juga bahwa transportasi merupakan bagian integral dari industri pariwisata.

Soekadijo (1997:160) menuturkan adanya sarana angkutan belum menjamin adanya trasnferabilitas. Untuk menjamin orang bepergian dari daerah satu ke daerah yang lain sarana angkutan harus memenuhi syarat: kenyamanan (comfort), waktu (time), dan biaya (rate). Kenyamanan sarana angkutan meliputi sebagai berikut. 1) Bentuk kendaraan, dengan bentuk yang mudah dikenal akan membantu orang yang akan menggunakannya. Tidak ada gunanya taksi bagus, bus bagus, kereta bagus atau pesawat bagus, tetapi orang tidak dikenali oleh orang yang berharap 
menggunakannya. 2) Fungsi kendaraan, kendaraan pertama kali harus berjalan dengan baik dan dapat diharapkan akan mencapai tujuan tanpa kerusakan mesin. Selanjutnya kendaraan mempunyai fasilitas tempat duduk yang cukup dan nyaman. 3) Lokasi kendaraan, di mana jasa kendaraan tersebut mudah diperoleh.Untuk mengakses lokasi yang merupakan tujuan utama, maka wisatawan akan menggunakan moda transportasi. Dari hal terebut hubungan antara pariwisata dan transportasi terutama sangat dipengaruhi oleh dua elemen (Tambunan, 2009), yaitu kemudahan mengakses tujuan (convenient access) dan kualitas layanan transportasi harus memenuhi harapan pengguna seperti tingkat keamanan, kenyamanan, frekuensi, efisiensi, dan keandalan.

Tujuan dasar dari penyediaan angkutan umum, (Wells dalam Tamin, 2000) adalah menyediakan pelayanan angkutan yang baik, handal, nyaman, aman, cepat dan murah untuk umum. Hal ini dapat diukur secara relatif dari kepuasan pelayanan beberapa kriteria angkutan umum ideal antara lain: 1) keandalan (setiap saat tersedia dan waktu singkat); 2) kenyamanan (pelayanan yang sopan, terlindung dari cuaca buruk, mudah turun naik kendaraan, tersedia tempat duduk setiap saat, tidak bersesak-sesak, interior yang menarik, dan tempat duduk yang enak); 3) keamanan (terhindar dari kecelakaan dan bebas dari kejahatan); 4) waktu perjalanan (waktu di dalam kendaraan singkat). Tingkat kepuasan inilah yang menunjukkan persepsi individu terhadap pemanfaatan angkutan umum. Hal ini sesuai dengan pendapat Rakhmat (dalam Murwati, 2014) yang menyatakan persepsi sebagai bentuk penilaian seseorang terhadap suatu peristiwa atau informasi yang terjadi dilingkungannya yang didasarkan pada pengalaman hidup seseorang. Sesuai konteks penelitian ini, tentunya yang diperlukan adalah persepsi dari wisatan di objek wisata budaya Kota Surakarta.

\section{METODE PENELITIAN}

Penelitian "Hubungan Persepsi Pengunjung terhadap Kualitas Transportasi Umum dengan Pemilihan Moda Transportasi di Kawasan Wisata Budaya Surakarta" merupakan penelitian deskriptif kuantitatif. Penggalian teori mengenai transportasi dan pariwisata terlebih dahulu dilakukan untuk mendapatkan variabel. Selanjutnya variabelvariabel tersebut menjadi hal yang diamati, dengan melihat langsung kondisinya di lapangan. Data yang didapat dari hasil observasi diberikan penilaian atau skor sehingga dapat diolah dalam bentuk angka dan dianalisis melalui prosedur statistik untuk mendapatkan hasil penelitian. Kebutuhan data yang digunakan dalam penelitian ini ada dua macam, yaitu data primer (diperoleh melalui pengamatan langsung di lapangan, angket/kuisioner, dan wawancara dengan informan terkait) dan data sekunder (diperoleh melalui studi literatur atau studi pustaka).

Pengambilan sampel pada penelitian ini menggunakan purposive sampling, yaitu teknik pengambilan sampel hanya pada individu yang didasarkan pada pertimbangan dan karakteristik tertentu (Suharsaputra, 2012:118). Sampel penelitian ini ialah pengunjung di Kawasan Wisata Budaya yang pernah menaiki atau menikmati transportasi umum di Kota Surakarta. Teknik pengumpulan data menggunakan kuesioner. Kuesioner yang digunakan merujuk pada alternatif jawaban skala Likert sehingga responden mudah memahami dan mudah menjawab pertanyaan. Adapun jawabannya berupa: sangat baik bernilai 5, baik bernilai 4, cukup baik bernilai 3, tidak baik bernilai 2, dan sangat tidak baik bernilai 1 . Dengan responden berjumlah 100 orang, maka dapat dihitung nilai tertinggi dengan nilai terendah sebagai berikut.

a. Nilai tertinggi adalah $500=100 \times 5$, dengan asumsi bahwa semua responden memberikan jawaban sangat setuju.

b. Nilai terendah adalah $100=100 \times 1$, dengan asumsi bahwa semua responden memberikan jawaban sangat tidak setuju.

c. Jarak $=\frac{\text { Nilai Tertinggi-Nilai Terendah }}{\text { Kelas }}$

d. Jarak $=\frac{400}{5}$

Jarak $=80$

Tabel 1. Kategori Penilaian terhadap Variabel Kualitas

\begin{tabular}{|c|c|}
\hline Nilai & Kategori \\
\hline $100-179$ & Sangat tidak baik \\
$180-259$ & Tidak baik \\
$260-339$ & Cukup baik \\
$340-419$ & Baik \\
$420-500$ & Sangat baik \\
\hline
\end{tabular}


Untuk perhitungan kategori penilaian persepsi pengguna terhadap kualitas transportasi umum adalah sebagai berikut.

Nilai Tertinggi

$=$ Total Pertanyaan $\times$ Total Responden $\times$ Bobot Tertinggi

$=13 \times 100 \times 5$

$=6500$

Nilai Terendah

$=$ Total Pertanyaan $\times$ Total Responden $\times$ Bobot Terendah

$=13 \times 100 \times 1$

$=1300$

Jarak

$=\quad$ Nilai Tertinggi - Nilai Terendah

$=5200$

$$
\begin{aligned}
& \text { Interval }=\frac{\text { Jarak }}{\text { Kelas }} \\
& \text { Interval }=\frac{5200}{5} \\
& \text { Interval }=1040
\end{aligned}
$$

Tabel 2. Kategori Persepsi Pengguna terhadap Kualitas Transportasi Umum

\begin{tabular}{|c|c|}
\hline Nilai & Kategori \\
\hline $1300-2339$ & Sangat Tidak Baik \\
$2340-3379$ & Tidak Baik \\
$3380-4419$ & Cukup Baik \\
$4420-5459$ & Baik \\
$5460-6500$ & Sangat Baik \\
\hline
\end{tabular}

Sumber: Zullianto, Agus, dkk; 2017

Data kualitas transportasi menggunakan data dikotomi dengan kriteria kualitas baik jika nilai $\geq$ rata-rata, dan kualitas tidak baik jika nilai < rata-rata.

Tabel 3. Skor Dikotomi Kualitas Transportasi Umum

\begin{tabular}{|l|c|c|}
\hline Kualitas Transportasi Umum & Keterangan & Skor \\
\hline Baik & nilai $\geq$ rata-rata & 2 \\
\hline Tidak Baik & nilai < rata-rata & 1 \\
\hline
\end{tabular}

Sumber: Zullianto, Agus, dkk; 2017

Teknik analisis yang digunakan yaitu metode analisis crosstab. Analisis menggunakan bantuan software berupa "PSAW Statistics 18" yang dijalankan pada sistem operasi Windows 7. Metode ini berbentuk tabel yang menampilkan tabulasi silang atau variabel kontingensi untuk mengidentifikasi ada tidaknya hubungan antarvariabel. Metode uji yang digunakan untuk mengetahui hubungan ialah uji chi-square-test.

\section{HASIL DAN PEMBAHASAN}

\subsection{Persepsi Kualitas Transportasi Umum Menurut Pegunjung Wisata}

Persepsi kualitas transportasi umum pada penelitian ini diuraikan dalam bentuk variabel yaitu kenyamanan, keandalan, keamanan, waktu, dan biaya. Adapun hasil analisis data diperoleh sebagai berikut.

\subsubsection{Kenyamanan}

Tolok ukur kenyamanan dalam penelitian ini meliputi bentuk moda, fungsi dan fasilitas, jangkauan, pelayanan petugas, tempat duduk, dan interior transportasi umum Kota Surakarta. Rata-rata pengunjung memberikan penilaian terhadap masing-masing aspek tersebut yakni cukup baik, artinya cukup nyaman. Dari keenam aspek tersebut satu di antaranya masuk ke dalam kategori baik yakni bentuk moda. Hal ini menandakan masih perlunya upaya peningkatan dari segi kenyamanan bertransportasi umum karena kenyamanan merupakan faktor penting dalam layanan transportasi publik. Senada dengan yang disampaikan oleh Soekadijo (1997), bahwa kenyamanan perjalanan erat kaitannya dengan 
fasilitas-fasilitas yang dimiliki angkutan, sehingga peningkatan fasilitas tentu akan meningkatkan kenyamanan pengguna transportasi. Hal ini sesuai dengan pendapat Soebiyantoro (2010) dalam penelitiannya yang mengungkap bahwa peningkatan pengembangan sarana dan prasarana dapat meningkatkan atraksi wisata di daerah. Dengan kata lain, adanya peningkatan kenyamanan transportasi umum akan meningkatkan penggunaan transportasi umum itu sendiri.

\section{a. Bentuk Moda}

Bentuk moda transportasi umum di Kota Surakarta termasuk ke dalam kategori baik. Hal ini membuat pengguna transportasi umum lebih mudah dalam memperoleh dan memilih moda transportasi tersebut. Apabila moda transportasi umum tersebut sulit dikenali maka pengguna akan kesulitan dalam memperoleh dan memilih moda transportasi umum tersebut. Hal ini sesuai dengan pendapat Soekadijo (1997) mengenai angkutan umum, bahwa bentuk kendaraan harus mudah dikenal supaya membantu orang yang akan menggunakannya karena sebagus apapun transportasi umum jika sulit dikenal maka tidak akan ada gunanya.

\section{b. Fungsi dan Fasilitas}

Fungsi dan fasilitas transportasi umum di Surakarta termasuk ke dalam kategori cukup baik. Hal ini menunjukkan fungsi dan fasilitas transportasi umum di Kota Surakarta cukup nyaman dan lengkap. Hal tersebut juga mengungkapkan fungsi dan fasilitas transportasi umum perlu ditingkatkan lagi untuk memberikan kenyamanan kepada pengguna transportasi umum.

\section{c. Jangkauan}

Jangkauan transportasi umum menentukan orang dalam memilih suatu moda transportasi, oleh karenanya sangat penting untuk diperhatikan. Transportasi umum harus melayani daerah-daerah yang terbilang vital seperti tempat wisata, sekolah, dan lain-lain. Perencanaan transportasi dalam hal ini sangat penting. Jangkauan transportasi umum di Kota Surakarta termasuk ke dalam kategori cukup baik. Ini menunjukkan bahwa jangkauan transportasi umum di Kota Surakarta cukup mudah dijangkau dan cukup mudah diperoleh. Soekadijo (1997) juga menuturkan bahwa kenyamanan angkutan umum dapat diperoleh apabila lokasi kendaraan umum mudah dijangkau atau mudah diperoleh.

\section{d. Pelayanan Petugas}

Berdasarkan data yang diperoleh pelayanan petugas yang dimiliki transportasi umum di Kota Surakarta termasuk ke dalam kategori cukup baik. Potensi tersebut dapat lebih ditingkatkan guna memberikan kenyamanan lebih baik kepada penumpang. Pelayanan petugas merupakan faktor penting dalam menciptakan suasana kenyamanan di dalam menggunakan transportasi umum. Kriteria pelayanan petugas saat ini dijadikan pendongkrak citra dari suatu perusahaan angkutan.

\section{e. Tempat Duduk}

Tidak dapat dipungkiri bahwa ketersediaan tempat duduk merupakan pertimbangan orang untuk menggunakan transportasi umum. Apalagi bagi penumpang yang sudah berusia lanjut akan sangat membutuhkan kenyamanan berupa ketersediaan tempat duduk. Penilaian tentang ketersediaan tempat duduk yang nyaman termasuk ke dalam kategori cukup baik. Hal ini menunjukkan masih ada beberapa penumpang yang tidak mendapatkan tempat duduk

\section{f. Interior}

Penilaian interior transportasi umum di Surakarta termasuk ke dalam kategori cukup baik. Padahal interior juga menjadi hal yang diperhatikan penumpang saat menikmati perjalanan. Perjalanan akan menyenangkan jika suasana di dalam juga menyenangkan. Hal itu menunjukkan pentingnya desain interior suatu transportasi umum. Hal tersebut menjadi potensi bagi transportasi umum dalam memberikan kepuasan kepada penumpang.

\subsubsection{Keandalan}

Keandalan merupakan hal yang harus dipenuhi pengelola transportasi umum untuk memikat masyarakat untuk naik transportasi umum. Ketersediaan transportasi dan ketepatan waktu memberikan kepuasan bagi pengguna. 


\section{a. Ketersediaan}

Ketersediaan transportasi turut menjadi hal yang diandalkan oleh beberapa orang terlebih orang tersebut bergantung pada transportasi umum untuk bergerak. Menurut penilaian pengunjung ketersediaan transportasi masuk ke dalam kategori cukup baik. Padahal semakin banyak transportasi umum yang melewati lokasi wisata, sebenarnya turut meningkatkan potensi wisatawan menggunakan transportasi umum. Tentunya hal ini berpengaruh pada waktu tunggu dan tingkat kejenakan wisatawan dalam menikmati lokasi wisata. Semakin banyak transportasi, tentu semakin sering transportasi tersebut melewati daerah-daerah wisata.

\section{b. Waktu Perjalanan}

Berdasarkan penilaian dilapangan diperoleh bahwa ketepatan waktu termasuk ke dalam kategori cukup baik. Hal ini menjadikan pertimbangan kepada penyedia jasa transportasi untuk terus meningkatkan pelayanannya. Terlebih dalam hal ketepatan waktu. Hal serupa juga diungkapkan Wells (1975) yang dikutip Tamin (2000) mengungkapkan kepuasan angkutan umum yang ideal salah satunya ialah keandalan ketepatan waktu perjalanan.

\subsubsection{Keamanan}

Keamanan merupakan salah satu faktor transportasi yang penting diperhatikan. Keamanan yang akan dibahas yaitu kemanan dari kemungkinan terjadinya kecelakaan dan keamanan dari terjadinya tindak kejahatan.

\section{a. Keamanan dari Kecelakaan}

Penilaian pengunjung mengenai keamanan dari kecelakaan masuk ke dalam kategori cukup baik. Aman adalah hal yang dibutuhkan setiap orang. Oleh karena itu penyedia jasa harus meningkatkan pelayanan keamanan guna menghadirkan perasaan aman pada transportasi umum. Nyoman Budhiartha (2011) dalam penelitiannya mengungkapkan bahwa salah satu faktor penting untuk menarik kedatangan wisatawan adalah keamanan pribadi. Oleh karena itu, tingkat keamanan transportasi umum di Kota Surakarta harus terus ditingkatkan. Hal ini diharapkan mampu meningkatkan kepercayaan wisatawan untuk menggunakan transportasi umum yang ada di Kota Surakarta.

\section{b. Keamanan dari Kejahatan}

Seperti halnya dengan aman dari kecelakaan. Aman dari kejahatan merupakan sauatu hal yang juga penting. Berdasarkan penilaian terkait hal tersebut penilaian aman dari kejahatan masuk ke dalam kategori cukup baik. Hal ini menunjukkan kepercayaan pengguna transportasi pada transportasi umum di Surakarta cukup tinggi. Karena sudah hampir semua armada transportasi umum sebenarnya juga akan lebih baik lagi apabila diberi CCTV. Dengan adanya CCTV, diharapkan keamanan dalam menggunakan transportasi umum semakin terjamin, serta dapat menjadi alat bantu dalam merekam setiap tindakan yang mengarah pada tindak kejahatan.

\subsubsection{Waktu}

Efisiensi waktu jarak kedatangan dan waktu yang diperlukan untuk melakukan perjalanan merupakan salah satu unsur penting yang biasanya dipertimbangkan wisatawan ketika menggunakan transportasi umum. Semakin lama waktu yang dibutuhkan wisatawan untuk menuju lokasi wisata, tentu akan mengurangi kenyamanan dalam berwisata.

\section{a. Jarak Kedatangan}

Waktu kedatangan transportasi umum di Surakarta tergolong cukup baik. Hal ini perlu ditingkatkan lagi agar penumpang tidak terlalu lama menunggu kedatangan transportasi umum. Apabila terlalu lama hal tersebut dapat mengurangi kenyamanan para pengguna transportasi umum. Oleh karena itu, jarak kedatangan juga penting untuk meningkatkan kenyamanan.

\section{b. Waktu Perjalanan}

Waktu tempuh perjalanan juga menjadi ukuran kenyamanan dalam menikmati transportasi umum. Semakin cepat waktu yang dibutuhkan semakin cepat kesempatan untuk menikmati waktu di lokasi tujuan (Soekadijo, 1997). Penilaian 
untuk waktu tempuh perjalanan termasuk dalam kategori cukup baik. Hal ini menunjukkan waktu tempuh perjalanan masih membutuhkan perhatian lebih lagi supaya pengguna layanan transportasi umum dapat memperoleh kepuasan serta kenyamanan

\subsubsection{Biaya}

Selain waktu, biaya merupakan suatu hal yang dijadikan pertimbangan untuk menggunakan transportasi umum. Adapun penilaian pengunjung terkait biaya transportasi umum di Surakarta termasuk ke dalam kategori baik. Artinya biaya transpotasi umum di Surakarta relatif tidak mahal. Menurut Wells (1975) yang dikutip Tamin (2000) Tujuan dasar dari penyediaan angkutan umum mengatakan bahwa menyediakan pelayanan angkutan yang baik salah satunya ialah biaya yang murah untuk umum.

Berdasarkan penilaian responden diketahui bahwa total nilai kuesioner yaitu sebesar 4101. Angka tersebut di dalam tabel termasuk kategori "cukup baik". Halini menunjukkan bahwa penilaian persepsi pengunjung terhadap transportasi umum tersebut adalah cukup murah. Artinya, terdapat potensi transportasi umum di Surakarta. Potensi tersebut masih perlu didukung dengan variabel-variabel lain untuk meningkatkan kualitas transportasi umum, sehingga peminat transportasi umum di Surakarta dapat meningkat.

\subsection{Pemilihan Moda Transportasi Pengunjung Wisata}

Data hasil kuesioner menunjukkan adanya macam-macam jenis moda transportasi yang digunakan pengunjung menuju lokasi wisata budaya Kota Surakarta. Pemilihan moda transportasi tersebut dapat dipengaruhi oleh berbagai faktor, salah satunya adalah kualitas transportasi umum. Meskipun dari analisis persepsi kualitas moda transportasi umum dikatakan baik, namun berdasarkan perolehan data mengenai pemilihan moda transportasi dari total 100 pengunjung, 65 di antaranya memilih menggunakan moda transportasi bukan umum. Sebanyak 35 pengunjung lainnya menggunakan moda transportasi umum sebagai cara menuju lokasi wisata.

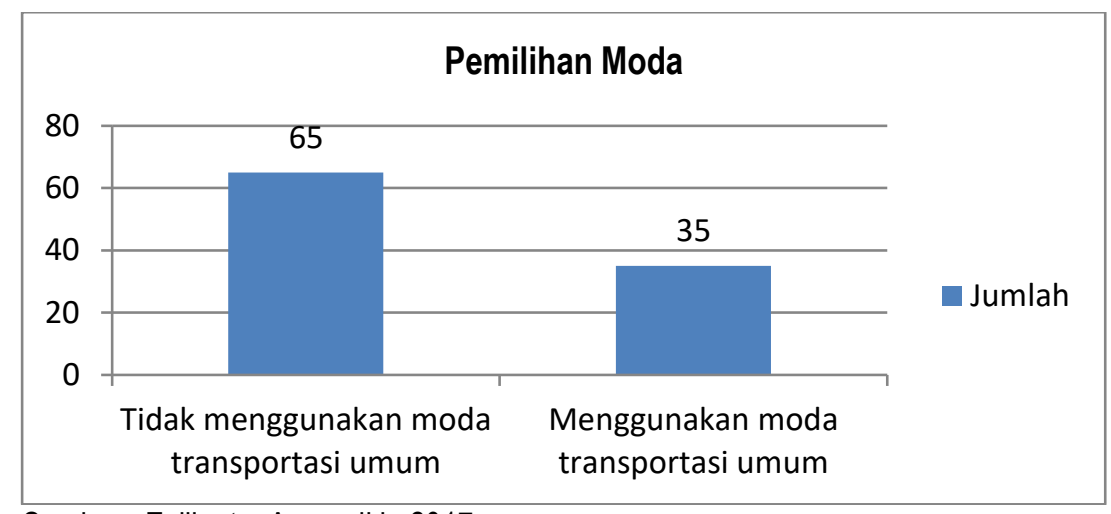

Sumber : Zullianto, Agus, dkk; 2017

Gambar 2. Grafik Pemilihan Moda Pengunjung

Moda transportasi umum yang digunakan pengunjung untuk menuju lokasi wisata meliputi bus, taksi, ojek, serta becak. Sebanyak 21 orang memilih menggunakan bus, becak sebanyak 6 orang, taksi sebanyak 4 orang, dan angkutan sebanyak 3 orang. Hal menarik, ternyata becak mampu melirik minat penumpang (wisatawan), sehingga berada di posisi dua sebagai transportasi umum yang banyak digunakan setelah penggunaan bus.

Adapun penggunaan moda transportasi bukan umum oleh pengunjung, yaitu berupa motor dan mobil. Motor sebagai pilihan moda transportasi bukan umum ternyata mendominasi sebesar 50 orang dari total 100 orang atau sebesar 50 persen. Disusul moda transportasi bukan umum berupa mobil sebanyak 15 pengguna dan ojek sebanyak 1 orang. 


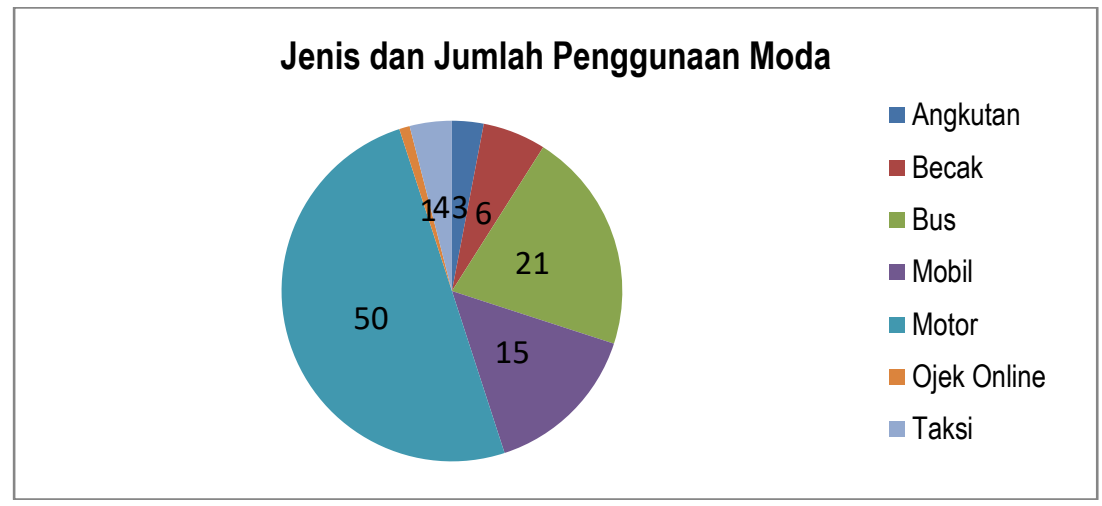

Sumber : Zullianto, Agus, dkk; 2017

Gambar 3. Diagram Jenis dan Jumlah Penggunaan Moda

Penggunaan moda transportasi bukan umum lebih mendominasi dibandingkan penggunaan moda transportasi umum. Fakta di lapangan menunjukkan hal serupa. Hal ini tidak dapat dipungkiri karena kualitas moda transportasi umum masih perlu ditingkatkan. Data lain menunjukkan beberapa responden tetap memilih menggunakan moda transportasi bukan umum, padahal mereka menganggap transportasi umum sebagai alat transportasi yang efektif menuju lokasi wisata budaya di Kota Surakarta. Berdasarkan hal tersebut, berarti terdapat faktor-faktor lain yang mempengaruhi seseorang memilih moda trasnsportasi selain variabel-variabel yang dijelaskan sebelumnya.

\subsection{Hubungan Persepsi Pengunjung terhadap Kualitas Transportasi Umum dan Pemilihan Moda}

Analisis ini bertujuan untuk mengetahui ada tidaknya hubungan kualitas transportasi umum dengan pemilihan moda transportasi. Analisis ini menggunakan analisis crosstab dengan memanfaatkan uji chi square. Berikut adalah hasil crosstab, chi square, dan symmetric measures:

\section{a. Output 1}

Dari 100 data yang diproses tidak ada yang missing atau hilang. Artinya data yang diproses semuanya berhasil seratus persen (valid).

Tabel 4. Case Processing Summary

\begin{tabular}{|c|c|c|c|c|c|c|}
\hline & \multicolumn{6}{|c|}{ Cases } \\
\hline & \multicolumn{2}{|c|}{ Valid } & \multicolumn{2}{|c|}{ Missing } & \multicolumn{2}{|c|}{ Total } \\
\hline & $\mathrm{N}$ & Percent & $\mathbf{N}$ & Percent & $\mathrm{N}$ & Percent \\
\hline $\begin{array}{l}\text { Kualitas Transportasi } \\
\text { Uumum * Pemilihan Moda }\end{array}$ & 100 & $100.0 \%$ & 0 & $.0 \%$ & 100 & $100.0 \%$ \\
\hline
\end{tabular}

Sumber : Zullianto, Agus, dkk; 2017

\section{b. Output 2}

Hasil output 2 menunjukkan hubungan variabel kualitas transportasi dan pemilihan moda. Persepsi responden yang menyatakan kualitas moda transportasi umum tidak baik menggunakan moda transportasi bukan umum sebanyak 42 orang dan 7 orang menggunakan moda transportasi umum. Sedangkan persepsi yang mengatakan kualitas transportasi baik menggunakan transportasi bukan umum sebesar 23 orang dan 28 orang sisanya menggunakan moda transportasi umum.

Tabel 5. Crosstab antara Kualitas Transportasi Umum dan Pemilihan Moda

\begin{tabular}{|c|c|c|c|c|}
\hline & & \multicolumn{2}{|c|}{ Pemilihan Moda Transportasi Umum } & \multirow{2}{*}{ Total } \\
\hline & & Bukan Umum & Umum & \\
\hline \multirow{3}{*}{$\begin{array}{l}\text { Kualitas Transportasi } \\
\text { Umum }\end{array}$} & Count & 42 & 7 & 49 \\
\hline & Expected Count & 31.9 & 17.2 & 49.0 \\
\hline & $\begin{array}{l}\text { \% within Kualitas } \\
\text { Transportasi Umum }\end{array}$ & $85.7 \%$ & $14.3 \%$ & $100.0 \%$ \\
\hline
\end{tabular}




\begin{tabular}{|c|c|c|c|c|c|}
\hline & & & Pemilihan Moda TI & ortasi Umum & \\
\hline & & & Bukan Umum & Umum & Total \\
\hline & & $\begin{array}{l}\text { \% within Pemilihan Moda } \\
\text { Transportasi Umum }\end{array}$ & $64.6 \%$ & $20.0 \%$ & $49.0 \%$ \\
\hline & & $\%$ of Total & $42.0 \%$ & $7.0 \%$ & $49.0 \%$ \\
\hline & Baik & $\begin{array}{l}\text { Count } \\
\text { Exnected Count }\end{array}$ & $\begin{array}{r}23 \\
332\end{array}$ & $\begin{array}{r}28 \\
179\end{array}$ & $\begin{array}{r}51 \\
510\end{array}$ \\
\hline & & $\begin{array}{l}\text { \% within Kualitas } \\
\text { Transportasi Umum }\end{array}$ & $45.1 \%$ & $54.9 \%$ & $100.0 \%$ \\
\hline & & $\begin{array}{l}\text { \% within Pemilihan Moda } \\
\text { Transportasi Umum }\end{array}$ & $35.4 \%$ & $80.0 \%$ & $51.0 \%$ \\
\hline & & $\%$ of Total & $23.0 \%$ & $28.0 \%$ & $51.0 \%$ \\
\hline Total & & Count & 65 & 35 & 100 \\
\hline & & Expected Count & 65.0 & 35.0 & 100.0 \\
\hline & & $\begin{array}{l}\text { \% within Kualitas } \\
\text { Transportasi Umum }\end{array}$ & $65.0 \%$ & $35.0 \%$ & $100.0 \%$ \\
\hline & & $\begin{array}{l}\text { \% within Pemilihan Moda } \\
\text { Transportasi Umum }\end{array}$ & $100.0 \%$ & $100.0 \%$ & $100.0 \%$ \\
\hline & & $\%$ of Total & $65.0 \%$ & $35.0 \%$ & $100.0 \%$ \\
\hline
\end{tabular}

Sumber : Zullianto, Agus, dkk; 2017

\section{c. Output 3}

Uji Chi Square Test menghasilkan angka Asymp.Sig(p) sebesar 0,000. Artinya hubungan antara kualitas transportasi umum dengan pemilihan moda transportasi terdapat hubungan yang signifikan. Hal ini dikarenakan nilai Asymp.Sig yaitu $0,000<0,005$.

Tabel 6. Chi-Square Tests

\begin{tabular}{|c|c|c|c|c|c|}
\hline & Value & df & Asymp. Sig. (2-sided) & Exact Sig. (2-sided) & Exact Sig. (1-sided) \\
\hline $\begin{array}{l}\text { Pearson Chi-Square } \\
\text { Continuity Correction } \\
\text { Likelihood Ratio } \\
\text { Fisher's Exact Test } \\
\text { Linear-by-Linear Association } \\
\mathrm{N} \text { of Valid Cases }\end{array}$ & $\begin{array}{r}18.121^{\mathrm{a}} \\
16.380 \\
19.088 \\
17.940 \\
100\end{array}$ & $\begin{array}{l}1 \\
1 \\
1\end{array}$ & $\begin{array}{l}.000 \\
.000 \\
.000 \\
\\
.000\end{array}$ & .000 & .000 \\
\hline
\end{tabular}

a. 0 cells $(.0 \%)$ have expected count less than 5 . The minimum expected count is 17.15 .

b. Computed only for a $2 \times 2$ table

Sumber : Zullianto, Agus, dkk; 2017

Meskipun hubungan antara kualitas transportasi umum dan pemilihan moda transportasi memiliki hubungan yang signifikan, masih ada beberapa pengunjung yang menggunakan pilihan moda transportasi umum di saat mereka mengatakan kualitas transportasi umum tidak baik. Begitu pun pada pilihan moda bukan umum, pilihan moda bukan umum tetap dipilih padahal mereka berpendapat bahwa kualitas transportasi umum baik. Berdasarkan hal tersebut ada dua kemungkinan yang terjadi. Pertama, pendapat kualitas transportasi umum tidak baik namun tetap memilih moda umum walaupun hanya beberapa. Kedua, pendapat kualitas transportasi umum baik namun pada kenyataan masih ada sebagian yang memilih moda transportasi bukan umum. Hal ini terjadi karena terdapat faktor-faktor lain di luar pembahasan yang tidak diketahui peneliti.

Tabel 7. Symmetric Measures

\begin{tabular}{|ll|r|r|}
\hline & \multicolumn{1}{|c|}{ Value } & Approx. Sig. \\
\hline Nominal by Nominal & Contingency Coefficient & .392 & .000 \\
N of Valid Cases & & 100 & \\
\hline
\end{tabular}

Sumber : Zullianto, Agus, dkk; 2017 
Adapun pada tabel 6 didapatkan nilai korelasi ( $r$ ) yaitu sebesar 0,392 yang artinya korelasi antara kualitas transportasi umum dengan pemilihan moda transportasi umum menurut persepsi pengunjung ialah berupa korelasi cukup kuat. Sehingga dapat disimpulkan bahwa persepsi mengenai kualitas transportasi umum berhubungan dengan pemilihan moda transportasi umum karena nilai korelasinya positif, maka arah korelasinya positif, artinya semakin tinggi kualitas transportasi umum akan semakin banyak yang memilih moda transportasi umum.

\section{KESIMPULAN}

Kualitas transportasi umum tentunya perlu senantiasa ditingkatkan untuk turut menarik minat masyarakat, terlebih wisatawan untuk menggunakan transportasi umum sebagai moda pilihan mengunjungi kawasan wisata budaya di Kota Surakarta. Persepsi kualitas transportasi umum dapat diketahui melalui beberapa variabel berikut. 1) Kenyamanan, meliputi bentuk moda, fungsi dan fasilitas, jangkauan, pelayanan petugas, tempat duduk, serta interior.2) Keandalan, meliputi ketersediaan transportasi dan ketepatan waktu. 3) Keamanan, meliputi kemanan dari kemungkinan terjadinya kecelakaan dan keamanan dari terjadinya tindak kejahatan. 4) Waktu, meliputi jarak kedatangan dan waktu perjalanan. 5) Biaya. Hasil penelitian ini menunjukkan bahwa pengunjung di objek wisata budaya Kota Surakarta memberikan penilaian "cukup baik" (sebesar 4101). Artinya, pihak-pihak terkait masih perlu memperbaiki dan meningkatkan kualitas transportasi umum sehingga peminat transportasi umum dapat meningkat.

Penilaian koresponden terhadap kualitas transportasi umum Kota Surakarta memang cukup baik, tetapi penggunaan moda transportasi bukan umum lebih mendominasi dibandingkan penggunaan moda transportasi umum. Beberapa responden bahkan tetap memilih menggunakan moda transportasi bukan umum, meskipun mereka menganggap dan menilai transportasi umum merupakan alat yang efektif untuk menuju lokasi wisata budaya di Kota Surakarta. Hal ini menandakan adanya faktor lain yang mempengaruhi seseorang memilih moda transportasi (selain variabel-variabel yang dijelaskan sebelumnya).

Hasil penelitian ini menunjukkan nilai $p=0,000$ dan nilai $r=0,392$. Maka dapat disimpulkan persepsi kualitas transportasi umum dengan pemilihan moda transportasi umum memiliki hubungan yang bermakna dengan korelasi yang cukup kuat, makin tinggi persepsi kualitas transportasi umum maka makin bertambah pemilih moda transportasi umum. Oleh karena itu, kualitas transportasi umum harus senantiasa ditingkatkan oleh pihak pengelola supaya peminat transportasi umum dapat meningkat.

\section{DAFTAR PUSTAKA}

Budhiartha, Nyoman. (2011). Peranan Transportasi dalam Pariwisata. Studi Kasus: Pemilihan Wisata (Dtw/ Destinasi) oleh Wisatawan di Bali. Jurnal IImiah Teknik Sipil, 15(2), 195-204.

Salim, Abbas. (2004). Manajemen Transportasi. Jakarta: Raja Grafindo Persada.

Soebiyantoro, Ugy. (2010). Pengaruh Ketersediaan Sarana Prasarana, Sarana Transportasi terhadap Kepuasan Wisatawan. Jurnal Manajemen Pemasaran, 4(1), 16-22.

Suharsaputa, Uhar. (2012). Metode Penelitian: Kuantitatif, Kualitatif, dan Tindakan. Bandung: Refika Aditama.

Soekadijo, R.G. (1997). Anatomi Pariwisata (Memahami Pariwisata sebagai "Systemic Linkage"). Jakarta: GramediaPustakaUtama Tambunan, Nani. (2009, Januari-Juni). Posisi Transportasi dalam Pariwisata. Majalah IImiah Panorama Nusantara, edisi VI, 39-48. Tamin, O.Z. (2000). Perencanaan dan Pemodelan Transportasi. Bandung: ITB.

Yudana, G dan A. Istijabatul. (2010). Pemetaan Transportasi Pariwisata sebagai Upaya Pengembangan Obyek dan Daya Tarik Wisata di Kabupaten Klaten. Laporan Penelitian Dibiayai DIPA BLU Fakultas Teknik Tahun Anggaran 2010. 